doi: $10.2478 / v 10221-011-0026-z$

\title{
Care pathways for the organization of patients' care
}

\section{Poti nege za organizacijo nege bolnikov}

\author{
Massimiliano Panella ${ }^{1,2}$, Ruben Van Zelm ${ }^{2,3}$, Walter Sermeus ${ }^{2,4}$, Kris Vanhaecht ${ }^{2,4}$ \\ ${ }^{1}$ Department of Traslational Medicine, University of Eastern Piedmont "A. Avogadro", Novara, Italy \\ ${ }^{2}$ European Pathway Association, Leuven, Belgium \\ ${ }^{3} Q$-Consult, Arnhem, The Netherlands \\ ${ }^{4}$ Centre for Health Services and Nursing Research, Faculty of Medicine, Catholic University Leuven, \\ Belgium \\ e-mail: panella@med.unipmn.it
}

pregledni znanstveni članek

UDK:616-07/-08

članek prispel: 25. 4. 2012; članek sprejet: 24. 5. 2012

citirajte članek kot / cite this article as:

Bilt - Ekon Organ Inform Zdrav 2012; 28(2): 111-122

\begin{abstract}
Care pathways, also known as clinical pathways, critical pathways or integrated care pathways, are used all over the world. Although they are used internationally, numerous misunderstandings still surround them. The goal of this paper is to provide an overview of the history of these pathways, of care pathway development, the effectiveness of care pathways, and of some of the challenges facing current healthcare.

Pathways are more than just a document in the patient record. They are a concept for making patient-focused care operational, and for supporting patient group modelling with different levels of predictability. Care pathways are a method within the field of continuous quality improvement and are used in daily practice as a product in the patient record. This paper explains these different issues.
\end{abstract}

Key words: patient care, patient safety, organization, clinical pathways

\section{Izvleček}

Poti nege, ki jih imenujemo tudi klinične poti, kritične poti ali integrirane klinične poti, se uporabljajo po vsem svetu. Čeprav je njihova uporaba mednarodno zelo 
razširjena, pa koncept poti nege še vedno spremljajo številni nesporazumi. V prispevku podajamo zgodovinski pregled poti nege, njihov razvoj in učinkovitost ter nekatere izzive zdravstvenega varstva danes.

Poti niso le dokument $v$ bolnikovem zdravstvenem kartonu, ampak mnogo več. Gre za koncept nege, ki je ciljno usmerjena k bolniku. Hkrati pa tudi pomembno podpira postopke modeliranja skupin bolnikov z različnimi stopnjami predvidljivosti. Poti nege so ena od metod, s katerimi nenehno izboljšujemo kakovost zdravstvenih storitev, $v$ vsakodnevni praksi pa se odražajo $v$ bolnikovem zdravstvenem kartonu. $\checkmark$ prispevku opisujemo različne vidike koncepta poti nege.

Ključne besede: nega bolnikov, varnost bolnikov, organizacija, klinične poti

\section{Background}

Standardizing care processes is an effective way to improve patient safety and quality of care. One of the main methods used to this purpose is the development and implementation of a care pathway $(1,2)$. The first systematic use of clinical pathways took place between 1985 and 1987 at the New England Medical Center in Boston (USA) in response to the 1983 introduction of Diagnosis Related Groups (DRGs) (3). Care pathways were introduced to the UK in the early 1990s and consequently their usage spread to the rest of Europe (4). Care pathways were primarily considered to be tools for designing care processes, implementing clinical governance, streamlining delivery of care, improving the quality of clinical care, and ensuring that clinical care is based on the latest research. Nowadays care pathways are used worldwide as one of the methods to structure or design care processes and improve them within the patient-centred care concept. In most countries, the prevalence of pathways is still rather meagre, especially when we consider that the care of $60-80 \%$ of patient groups in general hospitals should be suitable for pathway use (5). When developing pathways for these patient groups, we need to take into account the evidence based key interventions, the interdisciplinary teamwork, the patient involvement, and the available resources (6). This complexity makes it clear that introducing pathways into an organization and developing, implementing, and evaluating individual pathways is a complex intervention. Accordingly, the European Pathway Association (E-P-A, www.E-P-A. org) defines a care pathway as: A complex intervention for the mutual decision making and organization of predictable care for a well defined group of patients during a well defined period. Defining characteristics of pathways include: an explicit statement of the goals and key elements of care based on evidence, best practice, and patient expectations; the facilitations of the communication and coordination of roles, and sequencing the activities of the multidisciplinary care team, the patients, and their relatives; the documentation, monitoring, and 
evaluation of variances and outcomes; and the identification of relevant resources (7).

\section{Pathway development}

Several methods have been used for developing a care pathway. A good synthesis is represented by the 7-phase method (8) that is based on the Deming cycle, better known as the "plan-do-study-act" (PDSA) cycle (9). The 7-phase method aims at offering a systematic approach to support a multidisciplinary team that is developing a new pathway or aims to improve an existing pathway. Although the development, implementation and evaluation of a care pathway can be seen as following on the PDSA cycle, we use the 7-phase method as a series of linked PDSA cycles (see Figure 1). This supports the possibility of "rapid cycle improvement" (comparable to trial and error learning or learning by doing).

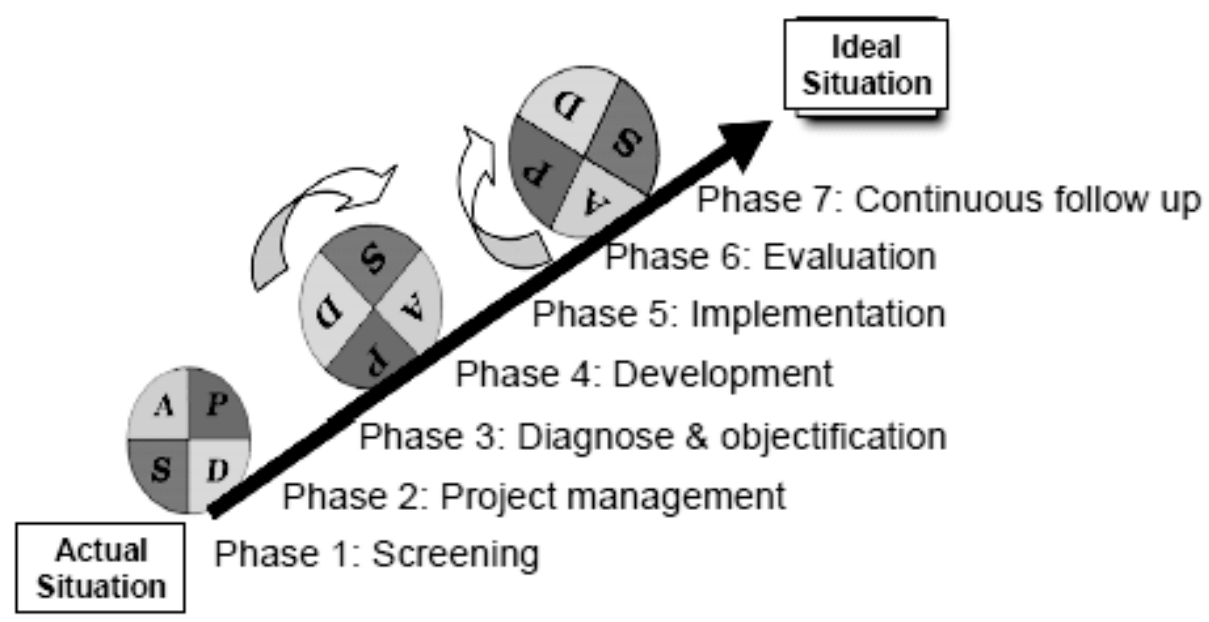

Figure 1. The 7-phase model for development, implementation and evaluation of care pathways. (8) 
In Table 1 we describe each phase of the model, including the objective of the phase and the main activities in that phase.

Table 1. The 7-phase model: objective and main activities per phase (8).

\begin{tabular}{|c|c|c|}
\hline Phase & Objective & Activities \\
\hline Screening & $\begin{array}{l}\text { Determine whether a care } \\
\text { pathway is the appropriate } \\
\text { method to improve the } \\
\text { care process }\end{array}$ & $\begin{array}{l}\text { Assemble and analyse information on: } \\
\text { - } \quad \text { Ownership, teamwork, stakeholders } \\
\text { - } \quad \text { The actual care process (readily } \\
\text { available information) }\end{array}$ \\
\hline $\begin{array}{l}\text { Project } \\
\text { management }\end{array}$ & 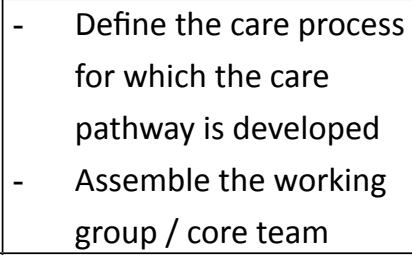 & $\begin{array}{ll}\text { - } & \text { Define patient group } \\
\text { - } & \text { Define start and endpoint of care } \\
\text { pathway } \\
\text { - } \quad \text { Set up projectplan, incl. milestones }\end{array}$ \\
\hline $\begin{array}{l}\text { Diagnosis and } \\
\text { objectification }\end{array}$ & $\begin{array}{l}\text { Evaluate the current (as } \\
\text { is) care process from four } \\
\text { perspectives: } \\
\text { a. Organization and team } \\
\text { b. Patient } \\
\text { c. Evidence and } \\
\text { legislation } \\
\text { d. External partners }\end{array}$ & $\begin{array}{l}\text { Analyse the sequence and timing } \\
\text { of the care process from these four } \\
\text { perspectives: } \\
\text { - Measurements of indicators, } \\
\text { questionnaires, process mapping } \\
\text { - Patient surveys, interviews, } \\
\text { shadowing of walkthroughs } \\
\text { Use of guidelines, clinical } \\
\text { algorithms, etc. }\end{array}$ \\
\hline Development & $\begin{array}{l}\text { Development of the } \\
\text { care pathway based on } \\
\text { information from the } \\
\text { previous phases }\end{array}$ & 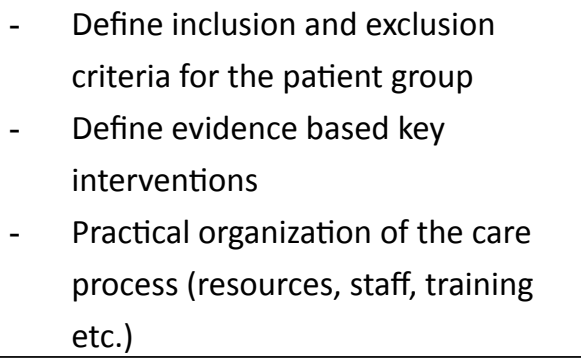 \\
\hline
\end{tabular}




\begin{tabular}{|c|c|c|}
\hline Phase & Objective & Activities \\
\hline Implementation & $\begin{array}{l}\text { Prepare the actual } \\
\text { implementation, test the } \\
\text { pathway and implement } \\
\text { the pathway }\end{array}$ & $\begin{array}{ll}\text { - } & \text { Informing and / or training of all } \\
\text { - } & \text { team members } \\
\text { - } & \text { Pilot testing of (elements of) the } \\
& \text { care pathway } \\
- & \text { Adjusting the care pathway based } \\
\text { on the test } \\
\text { - Implementation }\end{array}$ \\
\hline Evaluation & $\begin{array}{l}\text { Determine the effect } \\
\text { and usability of the care } \\
\text { pathway }\end{array}$ & $\begin{array}{ll}\text { - } & \text { Effect measurement } \\
\text { - } & \text { Measurement of adherence to the } \\
\text { - } & \text { pathway } \\
\text { - } & \text { Adjust care pathway if necessary } \\
& \text { Develop 'dashboard' for continuous } \\
\text { follow up }\end{array}$ \\
\hline $\begin{array}{l}\text { Continuous } \\
\text { follow up }\end{array}$ & $\begin{array}{l}\text { Keeping the pathway alive } \\
\text { and up to date }\end{array}$ & $\begin{array}{ll}- & \text { Use of indicators (dashboard) } \\
- & \text { Establish ownership } \\
- & \text { Variance analyses } \\
- & \text { Every six months substantive } \\
\text { discussion in core team } \\
- & \begin{array}{l}\text { Objective measurement at least } \\
\text { once a year }\end{array}\end{array}$ \\
\hline
\end{tabular}

\section{The effectiveness}

Since their beginning, care pathways had a tremendous appeal as a potential tool of quality improvement, to the point that hospital leaders concluded that the competitive environment did not allow the luxury of waiting for rigorous tests of the effectiveness of care pathways. (10) Despite the appealing logic of this approach, a healthy skepticism should remain about the pathways' true potential to improve quality. Looking back at the published reviews on the effectiveness of care pathways during the 2007-2012 period, some interesting findings can be observed.

Kwan (11) evaluated 15 pathways for acute stroke care and rehabilitation (3 Randomized Controlled Trials - RCT; $\mathrm{N}=340$ and 12 non-experimental studies; $\mathrm{N}=4081$ ). With a Cochrane systematic review, it was found that the pathways did not have a significant benefit on functional outcome, and that patient satisfaction and quality of life might actually be worse. On the other hand, a higher proportion, 
of patients receiving appropriate investigations, was observed in the pathways group, as well as a lower risk of developing certain complications such as infections and readmissions. The conclusion was that the evidence supported the use of care pathways for acute stroke but not for stroke rehabilitation.

Bailey (11) evaluated pathways for chronic cough in children. The search identified 471 potentially relevant titles but no studies met the criteria for inclusion in the review. Without further available evidence the authors did not make any recommendations for the use of care pathways for the treatment of chronic cough in children.

Lemmens (12) evaluated twenty-three studies regarding care pathways for gastrointestinal surgery, of which 16 were controlled studies. The studies assessed the most frequent complication rates, readmissions, mortality and length of stay and showed how care pathways for gastrointestinal surgery can enhance efficiency of care without any adverse effects on the outcome.

Chudyk (13) analyzed the effect of pathways on hip fracture rehabilitation continuum. According to their findings the adoptation of care pathways increased the use of intensive occupational therapy and/or physiotherapy exercise, enabled earlier surgery and mobilization, had a possible positive impact on functional recovery, decreased the Length of Stay - LOS, increased the appropriateness of the discharge destination for patients, but did not have any significant impact on mortality. Differences were also stronger after accounting for limited pre-existing disabilities and for providing social support among both groups.

Rotter (14) evaluated the use of care pathways for hospitalized children and adults of every age and indication. They selected 17 randomized controlled trials (RCT) and controlled clinical trials, representing 4,070 patients. They observed a significant shortening of LOS (the subgroup-analysis for invasive procedures showed a stronger LOS reduction with weighted mean difference -2.5 days versus -0.8 days). No evidence was found of differences in readmission to hospitals and for in-hospital complications. Four studies showed significantly lower costs for the pathway group.

The meta-analysis of Barbieri (15) evaluated the effect of pathways for hip and knee replacement. Twenty-two studies were included (1 RCT) for a total sample of 6,316 patients. The aggregate overall results showed significantly fewer patients suffering postoperative complications, shorter length of stay, lower costs during hospital stay and no significant differences in discharge to home.

Neuman (16) evaluated the care pathways for hip fracture for a total of 4,637 patients from 9 studies. The results showed lower odds of deep venous thrombosis, pressure ulcer, surgical site infection, and urinary tract infection for patients managed according to clinical pathways versus those receiving the usual care.

The review by Van Herck (17) included 34 of the 4055 publications about the effect of care pathways for total joint arthroplasty. The findings showed that pathways 
improved process and financial outcomes, but had mixed effects on clinical outcomes and that the evidence on team and service outcome was lacking. End-of-life care pathways have been evaluated by Chan, (18) including 920 potentially relevant titles, but no studies met the criteria for inclusion in the review. Therefore it was concluded that without further available evidence, recommendations for the use of end-of-life pathways in caring for the dying cannot be made. Moreover, they remarked how RCTs or other well designed controlled studies are needed for evaluating the use of end-of-life care pathways in caring for people nearing the end of life.

Lodewijckx (19) evaluated the impact of care pathways for in-hospital management of chronic obstructory pulmonary disease - COPD exacerbation. The studies described positive effects on blood sampling, daily weight measurement, arterial blood gas measurement, referral to rehabilitation, feelings of anxiety, length of stay, readmission, and in-hospital mortality. The authors also observed that statistical analyses were rarely performed, and that the trials used highly divergent indicators to evaluate the impact of the care pathways. Therefore, based on these studies, they concluded that the impact of care pathways on COPD exacerbation is inconclusive.

The systematic review on the effect of care pathways for hip fractures by Leigheb (20) assessed a wide range of outcome measures. While a number of divergent clinical outcomes were reported, most studies showed positive results of process management and health services utilization. In terms of mortality, the results provided evidence for a positive impact of care pathways on in-hospital mortality. Most studies also showed a significantly reduced risk of complications, including medical complications, wound infections and pressure sores. Moreover, time-span process measures showed that an improvement in the organization of care was achieved through the use of care pathways. Conflicting results were observed with regard to functional recovery and mobility between patients treated with care pathways compared to usual care.

In conclusion to this section, we have to state that the published effects of care pathways are ambiguous at the least. There are positive as well as negative results in clinical outcomes (e.g. complications, functional status), service outcomes (e.g. patient satisfaction), and financial outcomes (e.g. length of stay). Another important finding in most of the reviews cited above is that the individual studies included in the reviews have a relatively weak design. Therefore, we think that these findings indicate the need for further research; in particular we think that it will be necessary to design stronger research to evalute care pathways. For example, we believe that we could better understand the effectiveness of care pathways by performing cluster randomized controlled trials to evaluate the impact of care pathways on performance of care processes, clinical outcomes, and teamwork when treating patients with different conditions. 


\section{New challenges}

The rise of chronic diseases represents major challenges for actual health care systems. $(2,21,22)$ Most developed countries are facing growing health care costs due to an ageing population in which $70 \%$ of health care expenses are related to chronic diseases, (23) while the current fragile economic climate may progressively limit resources available to health care systems. (21) Another challenge lies in the actual organization of health care delivery systems. Current health care delivery systems are often unable to meet the complex needs of chronically ill patients for several reasons. (24) Firstly, health care is traditionally focused on acute care management and short term goals. (24) Secondly, the fragmented delivery of health and social services, including disconnection of primary and secondary care, is an acknowledged problem in many health care systems. $(2,24-26)$ Thirdly, too often chronic care approaches feature an uninformed, passive patient interacting with a poorly coordinated team of health professionals, resulting in frustrating and inadequate encounters. (27-29) Finally, despite the availability of worldwide evidence-based practice guidelines for a wide range of chronic diseases, the use of evidence based standards remains limited. $(2,21,30)$

A well-established model designed to guide the reorganization of healthcare delivery systems from acute and reactive care to proactive, planned and community-based care, is the Chronic Care Model (CCM) developed by Wagner et al. (1996). (29) In this systemic model, improved functional and clinical outcomes of disease management are the results of productive interactions between informed, activated patients and the prepared, proactive practice team of health care professionals. These productive interactions are supported by six components: health care organization, community resources, self-management support, delivery system design, decision support, and clinical information systems. (24) To better integrate aspects of prevention and health promotion into the CCM, an enhanced version called the Expanded Chronic Care Model was developed by Barr et al. (31)

The CCM has been used widely to guide the reorganization of health care delivery systems, however, implementation has been shown to be fragmented and limited to one or two components, mostly self-management, multidisciplinary teamwork and information systems. $(13,14)$ This defragmented and limited implementation may explain today's poor integration of care across organizations, the unbalanced skill mix and the lack of patient involvement in the current health care delivery systems. Furthermore, practices and changes in strategies used to reorganize health care according to CCM delivery systems vary significantly across health care systems. (32-34)

A possible strategy to facilitate the integration of all CCM components is the implementation of a care pathway. $(21,35)$ A care pathway bridging the gap between primary care and hospitals, that allows multidisciplinary teams to interact 
with active patients and communities, and which is facilitated by information technologies, can encounter defragemented implementation of the CCM, and has an enormous potential in optimizing patient care and outcomes such as hospital admissions and quality of life. $(21,35,36)$ As it has been mentioned before, the impact of care pathways on compliance to care processes and performance of outcomes is already being extensively evaluated for acute in-hospital setting. (14, $29,37,38)$ However, the focus of chronic care needs to shift towards addressing people in all stages of chronic disorders, including the early stages, and managing stable and long-term conditions. To develop an effective care pathway incorporating preventive, acute and long-term care, we need to know which components, and more specifically which best practices are essential for the proper functioning and effectiveness of that care pathway. $(35,39,40)$ However, as addressed earlier, due to de-fragmented and diverse CCM implementation strategies, and the use of diverse outcome measures, we can not know the active essential components and practices necessary to develop a structure for these integrated chronic care pathways. For this reason we think that some areas of research should be included in the agenda for further challenges in care pathways.

First it will be necessary to identify the best practices describing "coordination of care across organizations and across boundaries". This will facilitate the shift from hospital-centred systems towards integrated care systems, including managed clinical networks, multidisciplinary teams and collaborative flexible sharedcare arrangements between primary care and hospitals, and across the lines of healthcare believed to reduce inequalities and enhance equitable access to high quality and safe care.

We then believe it will be necessary to develop best practices on "knowledge translation into practice" and "clinical information systems" that will promote evidence-based policy-making and decision making, supported by adequate health information systems. This will probably also promote the use of modern technology (such as smart phones and applications) and will improve patient access, information and disease monitoring, which is expected to lead to cost savings.

Finally, action should focus on insights to cost information, which should help governments to allocate budgets for healthcare more efficiently.

In conclusion we believe that a new care pathway model including best practices is necessary for the reorganization of chronic care according to CCM. Such reorganization is necessary to deal with the current challenges of the growing rise in chronic diseases, the ageing population and the inevitable shift from hospitalcentred medicine to home care, and from physician care to nurse care and selfmanagement. 


\section{References}

1. Kohn LT, Corrigan JM, Donaldson MS. To Err Is Human: Building A Safer Health System. Washington: National Academies Press, 1999.

2. Committee on Quality of Health Care in America loM. Crossing The Quality Chasm: A New Health System for the 21 st Century. Washington: National Academies Press, 2001.

3. Zander K. Integrated Care Pathways: eleven international trends. J Integrated Care Pathways 2002; 6: 101-7.

4. Bailey EJ, Morris PS, Kruske SG, Chang AB. Clinical pathways for chronic cough in children. Cochrane Database of Systematic Reviews 2008, Issue 2. Art. No.: CD006595. DOI: 10.1002/14651858.CD006595.pub2.

5. Vanhaecht K, Bollmann M, Bower K, Gallagher C, Gardini A, Guezo J, et al. Prevalence and use of clinical pathways in 23 countries - an international survey by the European Pathway Association E-P-A.org. J Integrated Care Pathways 2006; 10: 28-34.

6. Vanhaecht K, De Witte K, Sermeus W. The care process organisation triangle: a framework to better understand how clinical pathways work. J Integrated Care Pathways 2007; 11: 1-8.

7. Vanhaecht K, De Witte K, Sermeus W. The impact of clinical pathways on the organization of care processes. Leuven: ACCO; 2007.

8. Vanhaecht K, Van Gerven E, Deneckere S, Lodewijckx C, Janssen I, Van Zelm R, et al. The 7-phase method to design, implement and evaluate care pathways. Int J for Person Centered Medicine, 2012 (in press).

9. Deming, WE. Out of the crisis Syndicate of the University of Cambridge, Melborne, 1982.

10. Pearson SD, Goulart-Fisher D, Lee TH. Critical pathways as a strategy for improving care: problems and potential. Ann Intern Med 1995; 123(12): 941-8.

11. Kwan J, Sandercock PAG. In-hospital care pathways for stroke. Cochrane Database of Systematic Reviews 2004, Issue 4. Art. No.: CD002924. DOI: 10.1002/14651858.CD002924.pub2.

12. Lemmens L, Van Zelm RT, Vanhaecht K, Kerkkamp H. Systematic review: Indicators to evaluate effectiveness of clinical pathways for gastrointestinal surgery. J Evaluation in Clinical Practice 2008; 14: 880-7.

13. Chudyk AM, Jutai JW, Petrella RJ, Speechley M. Systematic review of hip fracture rehabilitation practices in the elderly. Arch Phys Med Rehabil 2009; 90(2): 246-62.

14. Rotter T, Kinsman L, James EL, Machotta A, Gothe $H$, Willis J, et al. Clinical pathways: effects on professional practice, patient outcomes, length of stay and hospital costs. Cochrane Database of Systematic Reviews 2010, Issue 3. Art. No.: CD006632. DOI: 10.1002/14651858.CD006632.pub2

15. Barbieri, A, Vanhaecht K, Van Herck P, Sermeus W, Faggiano F, Marchisio S, et al. Effects of clinical pathways in the joint replacement: A meta-analysis. BMC Medicine 2009; 7: 32.

16. Neuman MD, Archan S, Karlawish JH, Schwartz JS, Fleisher LA. The Relationship 
between Short-Term Mortality and Quality of Care for Hip Fracture: A MetaAnalysis of Clinical Pathways for Hip Fracture. J Am Geriatrics Society 2009; 57: 2046-54.

17. Van Herck P, Vanhaecht $K$, Deneckere S, Bellemans J, Panella M, Barbieri A, et al. Key interventions and outcomes in joint arthroplasty clinical pathways: a systematic review. J of Evaluation in Clinical Practice 2010; 16, 1: 39-49.

18. Chan R, Webster J. End-of-life care pathways for improving outcomes in caring for the dying. Cochrane Database of Systematic Reviews 2010, Issue 1. Art. No.: CD008006. DOI: 10.1002/14651858.CD008006.pub2.

19. Lodewijckx C, Sermeus W, Panella M, Deneckere S, Leigheb F, Decramer M, et al. Impact of care pathways for in-hospital management of COPD exacerbation: a systematic review. Int J Nurs Stud 2011; 48: 1445-56.

20. Leigheb F, Vanhaecht K, Sermeus W, Lodewijckx C, Deneckere S, Boonen S, et al.The Effect of Care Pathways for Hip Fractures: A Systematic Review. Calcif Tissue Int. 2012 Apr 3. [Epub ahead of print]. DOI: 10.1007/s00223-012-95892.

21. European Respiratory Society. European Respiratory Roadmap: Recommendations for the future respiratory medicine. Available 10.11.2011 on:http://www.ersroadmap.org/.

22. Smith MT, Francis MD, Corrigan JM. Health care quality in the 21st century. Clin Exp Rheumatol 2007; 25: 3-5.

23. Christensen K, Doblhammer G, Rau R, Vaupel JW. Ageing populations: the challenges ahead. Lancet 2009; 374: 1196-208.

24. Wagner EH, Austin BT, Davis C, Hindmarsh M, Schaefer J, Bonomi A. Improving chronic illness care: translating evidence into action. Health Aff 2001; 20: 6478.

25. Bodenheimer T, Wagner EH, Grumbach K. Improving primary care for patients with chronic illness. JAMA 2002; 288: 1775-9.

26. Strandberg-Larsen M. Measuring integrated care. Dan Med Bull 2011; 58: B4245.

27. Neubauer K, Kidd E. Investing in Europe's Health Workforce of Tomorrow: Scope for Innovation and Collaboration. Summary Report of the Three Policy Dialogues. Leuven: European Observatory on Health Systems and Policies, 2010.

28. Sonetti DA, Hospenthal AC, Adams SG. Integrated management strategies for chronic obstructive pulmonary disease. J Multidiscip Healthcare 2010; 3: 1818.

29. Wagner EH, Austin BT, Von KM. Organizing care for patients with chronic illness. Milbank Q 1996; 74: 511-44.

30. Berwick DM. Disseminating innovations in health care. JAMA 2003; 289: 196975.

31. Barr VJ, Robinson S, Marin-Link B, et al. The expanded Chronic Care Model: an integration of concepts and strategies from population health promotion and the Chronic Care Model. Hosp Q 2003; 7: 73-82.

32. Coleman K, Austin BT, Brach C, Wagner EH. Evidence on the Chronic Care Model in the new millennium. Health Aff 2009; 28: 75-85. 
33. Weingarten SR, Henning JM, Badamgarav E, et al. Interventions used in disease management programmes for patients with chronic illness-which ones work? Meta-analysis of published reports. BMJ 2002; 325: 925.

34. Pearson ML, Wu S, Schaefer J, et al. Assessing the implementation of the chronic care model in quality improvement collaboratives. Health Serv Res 2005; 40: 978-96.

35. Vanhaecht K, De Witte K, Sermeus W. The Care Process Organisation Triangle: A framework to better understand how clinical pathways work. Int J Care Pathw 2007; 11: 1-8.

36. Seemungal TA, Hurst JR, Wedzicha JA. Exacerbation rate, health status and mortality in COPD: a review of potential interventions. Int J Chron Obstruct Pulmon Dis 2009; 4: 203-23.

37. Sermeus W, De Bleser L, Depreitere R, Dewaele K, Vanhaecht k, Vlayen J. An introduction to clinical pathways. In: Devriese $S$, Lambert $M$, Eyssen $M$ et al. (eds). The use of clinical pathways and guidelines to determine physicians' hospital fees prospectively: easier said than done. Belgian Healthcare Knowledge Centre (KCE). KCE Reports, Volume 18A. Availabe 20.10.2011 on: http:/www.kenniscentrum.fgov.be/nl/publicaties.html.

38. Van Herck P, Vanhaecht k, Sermeus W. Effects of Clinical Pathways: do they work? Journal of Integrated Care Pathways. J Integr Care Pathways 2004; 8: 95-105.

39. Medical Research Council. Developing and evaluating complex interventions: new guidance. 2008. Available 24.7.2011 on: http://www.mrc.ac.uk/Utilities/ Documentrecord/index.htm?d=MRC004871.

40. Panella $M$, Vanhaecht $\mathrm{K}$. Is there still need for confusion about pathways? Int J Care Pathw 2010; 14: 1-3. 